\section{Present and Absent: Exploring the Holocaust of Jews in Prague Using a Mobile Application}

GI_Forum 2020, Issue 2

Page: $14-28$

Full Paper

Corresponding Author: frankl@mua.cas.cz

DOI: 10.1553/giscience2020_02_s14

\author{
Michal Frankl', Petr Mazánek², Aneta Plzáková33, Wolfgang Schellenbacher', \\ Zuzana Schreiberová ${ }^{4}$ and Luboš Světík ${ }^{2}$ \\ 'Masaryk Institute and Archives of the Czech Academy of Sciences, Czech Republic \\ 2Deep Vision, Czech Republic \\ ${ }^{3}$ Terezín Initiative Institute, Czech Republic \\ ${ }^{4}$ Multicultural Center Prague, Czech Republic
}

\begin{abstract}
This paper discusses the goals, methodology and experience gained in the project 'Integration and Segregation in Cityspace: The History of the Holocaust in Prague Through a Web Application', funded by the Technology Agency of the Czech Republic. Using a mobile application, the project aims to overlay the current cityscape with extensive datasets on the Holocaust victims who were living in Prague before their deportation. By giving insights into working with the data, and by presenting the digitized material used and the technical development of the web application, the paper also hopes to contribute to future approaches for archival and educational GIS-based applications. Following an introduction to the spatial history of Jews in Prague, the article analyses the challenges at the crossroads of documentation and digitization, technology and user interface, as well as user interaction with data.
\end{abstract}

\title{
Keywords:
}

Holocaust, Prague, mobile application

\section{Introduction}

Due to the rapid exclusion, disenfranchisement and expulsion of Austrian Jews following the Anschluss of Austria to the German Reich, Ernst (Arnošt) Löwit, an Austrian bank assistant born in 1889, was forced to flee from Vienna to Prague in July 1938. He rented a room in Čermákova 9 in Královské Vinohrady / Königliche Weinberge, a middle-class neighbourhood, and became dependent on the support of the Jewish Community in Prague. Following the occupation of Czechoslovakia in March 1939, he tried in vain to prepare his further emigration to Shanghai. In 1941, he received a summons for a transport from Prague. Ernst Löwit was arrested on 18 October 1941 in a café on Charles Square in Prague: he had removed his Star of David to meet his non-Jewish fiancée Ludmilla Klimt and bid her farewell. Showing the 
intricacy of the day-to-day interactions in the city, he was found and punished after being denounced anonymously to the Czech police ${ }^{1}$.

After two weeks in prison, on 30 November 1941 he was transported to the ghetto in Terezín (Theresienstadt) ${ }^{2}$. A month later, several inmates in the camp were arrested, Ernst Löwit included, for illegally sending letters out of Terezín (Adler, 1960, p. 86). In an exemplary punishment, the SS hanged him together with eight other inmates on 10 January 1942, a mass execution unique in the history of the Terezín Ghetto $^{3}$.

The story of Ernst Löwit underlines how the persecution of Jews under the Nazi regime began in the space of everyday life in cities: in private homes, public spaces or workplaces. In education and public history projects, persecution during the Holocaust is easier to communicate using historical places of exclusion and extermination, which are often separated from the spaces of everyday life. However, mobile maps and the constant accessibility of information, as well as more experimental technologies such as augmented reality, are changing our perception of the present as we move around these public spaces. As pointed out in recent studies, historical geo-apps can function as an interface between the user and information on the real/virtual space (Bollini et al., 2014).

In recent decades, Holocaust-related research institutions have seen a massive shift in the nature of their work due to the 'digital turn': the digitization of large quantities of Holocaustrelated archival material has made it possible for archival content to be connected with individual entries in victim databases. In various countries, local digital projects are currently experimenting with ways of making data on persecution available in the public space via web and mobile technology, using new approaches to the numerous large and small datasets that document names of Holocaust victims created by Holocaust archives and memorial institutions.

This trend was also clearly demonstrated by an international workshop, 'It happened here! Digital and shared: Holocaust history in public space', organized by the European Holocaust Research Infrastructure (EHRI) in April 20194. The call to critically explore how digital approaches contribute to the social construction of space resulted in a surprising number of proposals and highlighted how topical such research and projects are. The growing application of spatial studies to Holocaust research provides a framework that leads historians to ask new research questions and to deploy geographic visualizations of the Holocaust (Cole, 2016; Knowles et al., 2014). Studies on the user experience of spatial mobile apps containing historical information have already shown the importance of the user's own vicinity. This underlines the need to expand user-testing methodologies to include the use of prototypes directly in the field (Bollini et al., 2014). The application for educational work in the field of

\footnotetext{
${ }^{1}$ National Archives Prague (NA), Policejní ředitelství v Praze (Police Headquarters Prague, PP), 1941-1950, call number L 1507/3 Löwit Arnošt.

2 NA Prag, PP, 1931-1940, call number D 391/51 Deutsch Oskar, Verhaftungsprotokoll.

3 Jewish Museum in Prague (JMP), call number SHOAH/T/2/A/2d/071b/001, Verzeichnisse inhaftierter Ghettoinsassen in Theresienstadt.

${ }^{4}$ See https://vwi.ac.at/index.php/veranstaltungen/icalrepeat.detail/2019/04/01/263/-/it-happened-heredigital-and-shared-holocaust-history-in-public-space (30.1.2020) for workshop programme.
} 
Holocaust research is still in its infancy, however, making the experiences of earlier similar projects even more important.

This paper gives insights into the questions and methodologies of one of these projects: 'Integration and Segregation in Cityspace: The History of the Holocaust in Prague Through a Web Application', funded by the Technology Agency of the Czech Republic, which projects data from the database of victims into the present cityscape of Prague, using a mobile application. For its implementation, an interdisciplinary team joined forces: the Terezín Initiative Institute (TII), a documentation and educational institution; the Masaryk Institute and Archive of the Czech Academy of Sciences, a research institution; the Multicultural Centre Prague, an educational institute; and Deep Vision, the technological partner institution. Drawing on experience from similar projects, it contributes to the exploration of how historical data on individuals, locations and events can mobilize local knowledge and participation. It works closely with the online application 'Memento Vienna' (Schellenbacher, 2017), which currently makes available data on more than 55,000 victims of the Nazi regime in Vienna and is based on the database of victims of the Documentation Centre of Austrian Resistance $^{5}$. Using a map of the city, the mobile website makes visible the last-known addresses of those murdered, and connects the people and places with archival documents and photographs.

This paper discusses both the challenges of developing a mobile application mapping the persecution of the Jewish residents of Prague after 1939, and fresh approaches to the development of the application. By giving insights into working with the data, the digitized material used and the technical development of the web application, the paper also aims to contribute to future approaches for archival and educational GIS-based applications. Following a short introduction to the history of Jews in Prague (Section 2), the article analyses the challenges at the crossroads of documentation and digitization, technology and user interface, as well as user interaction with data.

\section{Jews in Prague: A spatial history}

The emancipation of Jews, as well as its violent reversal during WWII, was an inherently spatial process. While Prague's Jewish community could be proud of its continuity of settlement from the early Middle Ages (occasional and short-term expulsions notwithstanding), during the 19th and 20th centuries the patterns of Jewish presence underwent profound transformations, as did the city as a whole. These changes included the recoding of spaces, the development of new urban spaces, and increasing migration and mobility within the city.

The Prague Jewish Town, or the former ghetto, became a regular city neighbourhood in 1850 . The fifth administrative district, also called Josefov after the Emperor Joseph II who started the emancipation of Jews in the 1780s, was home to an increasingly diverse and mostly impoverished population. By 1890, only one third of the 11,535 inhabitants of the fifth district were Jews, and the historian Cathleen Giustino has described the transition of Josefov into a ‘slum' (Giustino, 2003b, pp. 89-114, 172; 2003a). In 1896, however, Prague City Council

\footnotetext{
${ }^{5}$ See www.memento.wien, current status July 2020.
} 
launched a long-prepared urban reconstruction programme known as 'asanace' or 'Assanierung' ('sanitization'). With the exception of selected synagogues and most of the Old Jewish Cemetery, by the outbreak of WWI the former ghetto had been torn down, and the neighbourhood was rebuilt in the fashionable, middle-class styles of the day (Giustino, 2003b; Hrůza, 1993).

While older Jewish spaces were in decline, new neighbourhoods gave Jews possibilities to integrate and flourish. The new sprawling suburb of Královské Vinohrady (Königliche Weinberge in German) invited the migration of Jews from smaller towns in Bohemia as well as from Prague's former Jewish Town. The impressive Vinohrady synagogue, built in the fashionable Moorish style and opened in 1897, became one of Prague's most visible landmarks - so much so that Czech anti-Semites perceived it as a symbol of Jewish dominance over Czechs and Christians (Šmok, 2015). Vinohrady offered ample spaces for middle-class social life in its parks, cafés and theatres. As the city grew, the Jewish population migrated to the new neighbourhoods. Especially in the public sphere and in professional life, Jews increasingly interacted with non-Jews (Koeltzsch, 2012). But as the historian Gary Cohen has calculated, while Jews and non-Jews shared the public space, they still gravitated towards the same residential spaces in their private lives (Cohen, 1977).

Jews co-produced the modern cityscape of Prague. For instance, Jiří (Georg) Kosta described in his memoires how in 1927 his grandfather, developing his artificial-flower business, built a modern functionalist house at the bottom of Václavské náměstí (Wenceslaus Square, one of the main squares and public spaces in Prague), next to the Bat'a shoe store, the celebrated symbol of the economic success of inter-war Czechoslovakia. To this day, the house is named after his grandfather (Lindtův dům). A passageway connects the highly frequented spaces of the Václavské náměstí with Jungmannovo náměstí (Jungmann Square) (Kosta, 2001, p. 18). Yet this presence in the public space, which was sometimes prominent, was not uncontested. The position of the Jewish population was subject to a double conflict: over their presence in middle-class spaces such as cafés, parks, theatres or public transport, and over language and national coding of space. With the growing intensity of the Czech-German nationality conflict, public spaces and the public use of languages became subjects of a bitter struggle. Prague Jews, many of whom spoke German or were bilingual (like Jiří Kosta), were often accused of 'Germanizing' (that is of spreading German loyalties among themselves and others (see e.g. Cohen, 1981). The same accusation was often directed against German-Jewish refugees from Nazi Germany who found a temporary and insecure refuge in Prague. Some lived in overcrowded homes on the outskirts; some - not allowed to work - spent their time walking the streets or sipping the same cup of coffee for hours in a café in the city centre (Čapková \& Frankl, 2012).

After the occupation by Nazi Germany in March 1939 and the creation of the Protectorate of Bohemia and Moravia, Jewish spaces rapidly shrank, often by order of the local authorities, from municipal councils to Czech 'autonomous' ministries (Adler, 1960; Gruner, 2016; Kárný, 1991). For instance, on 17 May 1940, just as the time for enjoying spring and summer strolls arrived, Jews were prohibited by the Prague police from entering public parks and gardens; mothers instead took their children to Jewish cemeteries, the only green spaces they were allowed to enter. Jews were prohibited from certain streets or riverbanks and had to move to overcrowded apartments. Synagogues were closed and turned into storage spaces for 
confiscated goods. With the ongoing revocation of rights, Jewish life underwent a spatial recentring: even those who were not particularly religious or who were 'Jews by race' (i.e. people who had converted to Christianity) were now increasingly dependent on Jewish communal institutions for emigration and social or health care (Bondy, 1989; Krejčová et al., 1997).

At the same time, new geographies of persecution emerged. For instance, the Nazi Zentralstelle für jüdische Auswanderung (Central Office for Jewish Emigration) in PragueStřešovice became a place of humiliation and terror (Černý, 1997; Milotová, 1997). On 16 October 1941, the first mass transport of Jews left Prague for the ghetto in Lódź (Lodz); soon transports departed on a regular basis to the newly established ghetto in Terezín (Theresienstadt), and from there to other ghettos and extermination camps. The systematic deportations produced a new geography: an internment camp was established in the grounds of an industrial exhibition area in Prague-Holešovice, from where approximately 45,000 deportees were led to the nearby Bubny railway station. Local inhabitants would see families with heavy suitcases containing the permitted $50 \mathrm{~kg}$ of personal belongings moving to the exhibition ground and then being marched to the station. Jews who were still allowed to live in their city, mostly those from 'mixed' families, were excluded from much of its space, and towards the end of the war many were interned at Hagibor, a Jewish sports club which had been turned into a forced labour camp.

Holocaust survivors returning from camps or from emigration found a changing city and shifting political climate. In 1946-47, the Jewish community counted 7,422 Jews defined by their religion, and 3,145 others considered Jewish by the Nazis under the Nuremberg Laws, who were still supported by the Jewish community. After the war and after the suppression of the Prague Spring in 1968, many Jews emigrated. As a result, the current official Jewish community has fewer than two thousand members.

Until the fall of state socialism in 1989, Holocaust memorials were largely confined to Jewish spaces such as cemeteries and synagogues. In the 1950s, the State Jewish Museum inscribed the names of approximately 80,000 Bohemian and Moravian Jews on the walls of the Pinkas Synagogue in Prague. However, the memorial was closed in 1968 and only reopened in 1996, once the museum was returned to the Jewish community. Because the Prague synagogues and most other Jewish sites were not physically destroyed in the 'Reichskristallnacht', the Jewish Museum became a major tourist attraction, symbolizing the void, but also representing what was labelled 'virtual Judaism' (Gruber, 2002; Veselská, 2012). Until recently, the places related to deportations were insufficiently marked and remembered. Thanks to an initiative by survivors, a memorial plaque was installed in 1989 close to the original collection point, and became a location for annual commemorations. Recently, as part of the general redevelopment of an extensive brownfield site, Bubny railway station began its transformation into a museum. Other memorials have also been unveiled, for instance a number of Stolpersteine set into the pavements in Prague by a local initiative.

\section{Database of the Holocaust victims}

Building on the unique database of the Holocaust victims managed by the TII, this project aims to unlock the potential of a large dataset through bringing it into the public space via 
maps and a mobile application. Similar to other projects documenting the names and fates of Holocaust victims, the database is the result of long-term coordinated research that began in the early 1990s, which itself built on earlier documentation activities. The first public outputs were a list, published in 1993, of 218 children who survived deportation to Terezín (Kárná, 1993); in 1995, the Terezín Memorial Book listing all deportees from Bohemia and Moravia followed (Kárný, 1995; Terezín Memorial Book, 1996). The book contains information on approximately 80,000 people deported from the Protectorate to Terezín, Minsk, Lodz and other ghettos and camps. In 2000 and 2005, the Terezín Memorial Books for prisoners from Germany and Austria respectively were published (Theresienstädter Gedenkbuch, 2000; Theresienstädter Gedenkbuch, 2005).

The core sources were lists of prisoners who died in Terezín or who were deported to extermination camps, compiled between 1968 and 1972 by the Jewish Committee for Terezín; the lists of survivors in Terezín published in 1945 for repatriation purposes (Spilka, 1945). This data was supplemented by information from transport lists to and from Terezín, card files of prisoners (held in the National Archives in Prague and at the Federation of Jewish Communities in the Czech Republic), as well as other archival sources, memorial books, personal testimonies and memoirs. The database is continuously updated and currently contains more than 170,000 individual records of which approximately 35,000 will be used for the Prague mobile application. In 2008, the victim database was published online as part of the holocaust.cz educational portal (Plzáková \& Štěpková, 2015).

The original database contained only personal data and no documents or photographs. In 2005, the TII embarked on an extensive digitization project, the Terezín Album, which aims to - symbolically - give faces to the victims and to open up a trove of documents to further research. While some documents and photos of the victims are from individual donors, this project focuses on the systematic processing of collections stored in Czech archives. Until 2012, the TII digitized personal files of the Police Directorate in Prague, held in the National Archives in Prague, and all the death certificates from the Terezín Ghetto, part of the Jewish Registers Collection. During this phase of the project, around 180,000 documents (more than 370,000 single pages and about 50,000 photographs) were scanned. Since 2013, the project has continued with a focus on communities outside Prague. The database is still person-centred and now allows for investigation into the lives of Holocaust victims in much greater detail.

\section{From data to social practice}

The purpose of the application is not purely commemorative. Starting from an awareness of the social construction of space, it builds on the data in the database of victims to establish a connection between the familiar space of the city and the complex history of encounters and conflicts in the multi-ethnic city of Prague. The application measures and tests the social impacts of data, and is an intervention in the public space designed to catalyse thinking about the mechanisms of inclusion and exclusion in everyday life. Using the application is understood as a social practice which affects not only users' knowledge, but also their perception of the places and spaces they frequent. To achieve this, and beyond what many similar applications offer, the project places particular emphasis on data which enrich the spatial experience and on awareness of the shared and disputed space. 
In doing this, the project aims to relocate where and how users (including residents, students and tourists) experience 'Jewish' Prague and the history of the Holocaust of Prague Jews. Hopefully, it will extend the geography of 'Jewish Prague' beyond the Jewish Town itself (where the Jewish Museum provides access to a number of sites and exhibitions). Moreover, by looking at tensions in the public space, it aims to reach beyond the usual commemorative function of projects locating Holocaust victims in their pre-war places of residence.

To connect the Holocaust victims to the city space, the team used the addresses listed during the registration of Jews which began in the autumn of 1941, just as mass deportations were launched. These addresses were checked, corrected and unified by adding the current street names to the historical German and Czech names from the 1940s. They were also automatically geocoded via BatchGeo, a software powered by Google Maps. In doing this, the project built on the experiences from the mobile web application 'Memento Vienna', but aimed for a more automated workflow combining data enrichment services with manual finalization. The digitized police files, such as passport and ID card applications containing photographs as well as residence permits and other types of routine documents, often allow for a reconstruction of information about an individual's residence, changes over time, employment, education, social and economic status, and family ties. In the application, these documents and photographs provide a possibility to (at least partially) reconstruct the victims' everyday life before 1939 and during the occupation.

The project team focused on what it called 'incidents', such as the arrest of Ernst Löwit, and invested time and resources in identifying documents that demonstrate interactions between Jews and non-Jews, as well as ordinary people and authorities in the city space. Even though this information is derived from the police archives and is necessarily one-sided, it can reveal details of social life before and during the occupation, the day-to-day enforcement of antiJewish decrees, and transgressions of them. At the same time, spaces of tension are revealed those where exclusion ran most dramatically against pre-war social practices. Unlike the deportations, which were decided on by the occupying authorities, the involvement of the local population and of Czech authorities are disputed subjects, disrupting the idealized picture of Czech national history. Documents on arrests and criminal cases provide unique data about the exclusion of Jews from society, and the spaces and situations of transgression. They include, for instance, investigations of Jews who entered spaces prohibited to them or did their shopping at times reserved for 'Aryans', as well as of Jews who were caught not wearing the obligatory Star of David or whose ID cards were not marked with the letter 'J'. At the time of writing, the team has identified and catalogued around 1,000 such 'incidents' which will be marked with a special icon in the application and, we hope, have a disruptive effect, making users think critically about public space and the participation of Czech society in the exclusion of a minority.

In the next phase, the team plans to add data on places of interest. While some of these may be tourist sites, the information will differ from standard tourist information by starting from the function of the location during the Holocaust. For instance, the history of a synagogue might point to its war-time use for storing 'aryanized' objects and the destruction of its community, rather than its long history and unique architecture. The project aims to map, at least partially, spaces prohibited to Jews, the sites of the Jewish community, major places of persecution and deportation, as well as selected places of memory. 
Importantly for turning data into an application, the space is not understood as a static phenomenon. Combining the map with a timeline allows a dynamic picture of presence and absence to emerge. Users will be able to move along the timeline to see the shrinking Jewish space, the points of conflict, and the vanishing Jewish life. The preliminary idea, still to be tested, is that objects on the map which symbolize people as well as points of interest will change colour as a result of persecution, exclusion and confiscation. For instance, an icon of a person will change to grey after deportation, and a synagogue, too, after being turned into a storage space. Visualizing absence is an essential ambition of the application.

\section{Challenges of technology}

To build an application which represents a rich and extensive dataset in space and time that is optimized for use by end-users as they move through the same space brings significant challenges. The project team decided to prioritize the building of native mobile applications for Android and iOS, rather than the originally planned responsive web application (which will only be created as a fall-back option). This decision was taken mainly in view of the technological advantages: access to the operating system's kernel, and the possibility of reading data from navigation sensors or the gyroscope. Implementing such features on a web platform is much more complicated and the solutions tend to be unstable. Given the large number of records and documents and their ongoing updating, the application will require an internet connection. The software stack used consists of Node.js as the server application layer, Nginx as the web server, GraphQL as the communication language, and React.native for building mobile applications. (The choice of the database server is discussed below, in this section.) The application code will be open source, with documentation regarding the data structure and import formats, so that it can be customized for similar projects elsewhere or those addressing other historical topics.

The resulting application will be centred around the representation of space and time, or a map and a timeline, in which we locate people (victims of the Holocaust), events (arrests or other incidents) and points of interest. The final version will also offer predefined guided tours. Two aspects of the technical development turned out to be particularly challenging - and interesting: the choice of the right database and data model, and the work with maps. (We discuss these further below.)

How to represent the complex data and provide smooth and effective access was a key question. The application needs to retrieve data from a large database based on connections between people, locations and events, and other supporting data types, and to display them in real time as end-users move through the streets. Although the project originally tested modelling data in a conventional relational database, it ultimately opted for a hybrid graph database. While relatively novel, graph databases have become more popular in recent years because of their flexibility and ability to retrieve information by following the relationships between data objects. A hybrid graph database proved an elegant solution for modelling a data structure which captures the local history of the Holocaust. A graph database, specifically ArrangoDB, allows for a better, more logical and effective data structure. 


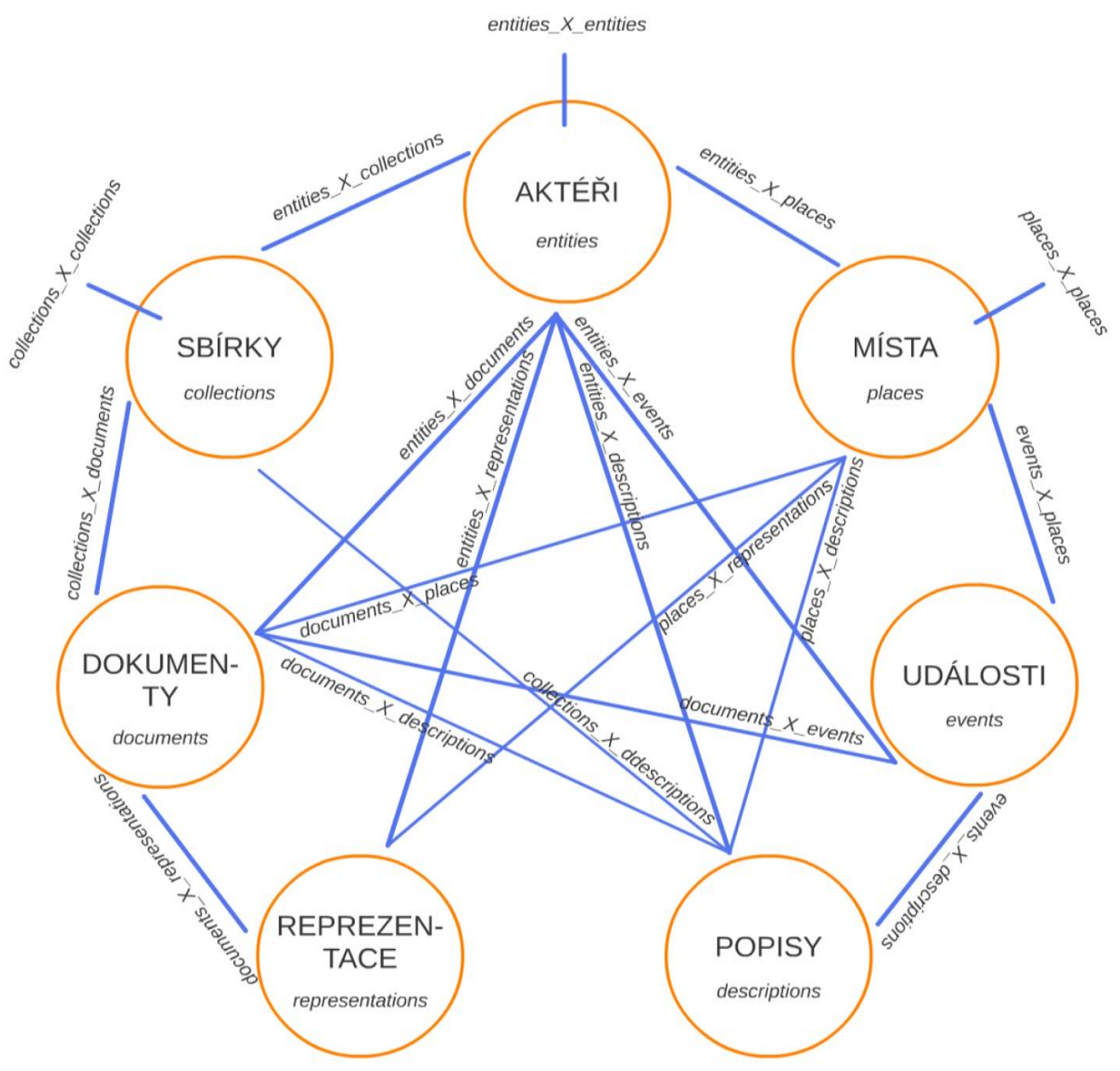

Figure 1: Schema of the data structure

The project opted for a generic data model applicable to any set of historical knowledge about people in space and time, thus making it useful for encoding not only the history of persecution, but also human agency. The core data elements (vertices) are people (Holocaust victims who lived in Prague before deportation), locations (places of residence, historical sites, places of interest etc.) and events (incidents involving the victims of the Holocaust, transports and other data). The sources of information are encoded as documents and collections, and the model is further extended by support data types of descriptions and representations. Most information, however, is located in the edges connecting the vertices, which allows the representation of a dynamic network of named relationships. The cost, however, is that the more generic model might be more difficult to adopt by projects with lower data expertise and technical capacity.

The application projects historical data into the present space. Hence mapping is a crucial element of its functionality. Since users are navigating through the current cityscape while 
accessing the information, the core map had to be based on the current street plan and includes current street and place names. The project team discussed the two standard possible solutions, OpenStreetMap and Google Maps, and eventually decided on the latter. While OpenStreetMap is free and the base map is often richer, its implementation would be more complicated, most likely requiring a dedicated map server. Google Maps, despite requiring fees based on the amount of access, offers good configuration of the user interface and rich possibilities for styling.

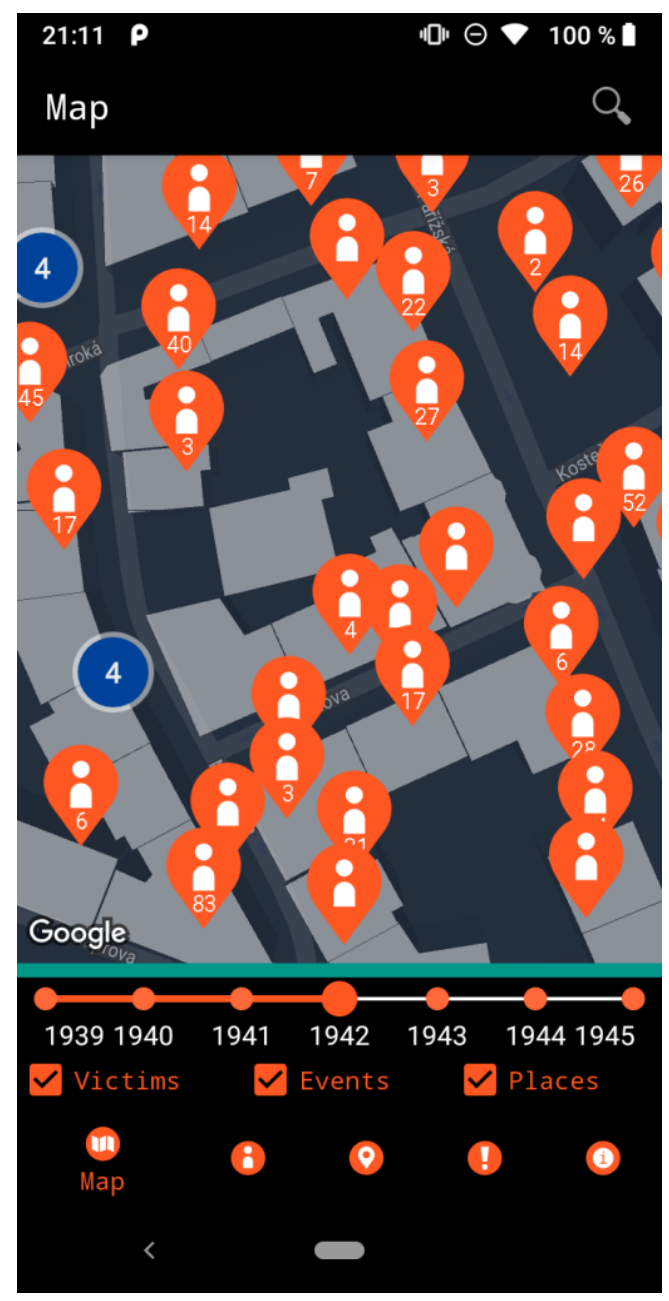

Figure 2: Development version of the application, showing map view with timeline

Implementing Google Maps, however, brought its own challenges, which were partly related to the focus of its standard layout on driving rather than walking, visually under-representing public spaces (such as squares) as a result. Moreover, the designers suggested a powerful dark graphic style which reduced the amount of detail and the readability of the map. Based on user 
feedback (discussed in Section 6) and a detailed exploration of the possibilities of the Google Map API, the map style in the application was upgraded to address these issues. The application may in the future overlay the Google Maps layer with a historical map layer; more research and testing are needed to better understand how users would navigate in the present space while using an historical map.

Early in the project, to allow for user testing and internal discussion by the project team, we first developed a test application which used just a very small subset of data and a conventional relational database. The next round of testing will be based on a new and feature-complete application using the full dataset (which was delivered as this paper was being finalized).

\section{Testing user experience}

While technology introduces its own challenges, the main challenge is the real-life interaction of end-users in the physical space of the city. In fact, we know very little about how students, residents or tourists use mobile devices to engage with history, especially when a large amount of data is made available. User testing and feedback from different groups of potential users are therefore essential aspects of the project. Before the development of the application itself began, the interaction of users with archival documents was examined, and testing continued after the release of every beta version of the application. The testing so far has been based on a partial dataset only and has lacked most of the data on 'incidents' and points of interest, as well as the visualization of absence.

The testing was conducted with small groups of users, and therefore qualitative research methods, especially participative observation, semi-structured interviews and focus groups, were used. (See for instance Lichtman, 2012; Delamont, 2012; Denzin \& Lincoln, 2011.) According to this methodology, the researcher must respond to ongoing results and circumstances and adapt the research plan accordingly. Researchers took notes during participative observation and analysed them in combination with interview transcripts, photographs and video recordings. We used rules and methods of qualitative questioning during semi-structured interviews, and moderated discussions in focus groups. Predetermined response formulations or categories were not provided to respondents, and a neutral stance was expressed in the questions. Each testing was conducted with a specific group of preselected participants: team members and external collaborators, children of Holocaust survivors, students of an IT school, and students in third grade at the Jewish grammar school in Prague (the Lauder School, itself located in a former Jewish orphanage, not far from where Ernst Löwit first found refuge in Prague).

Participants were given basic information about the project, and about the main goals and research methods. In the case of the Lauder School, cooperation was negotiated in advance and integrated in school activities. The testing with students at the Lauder School also used the peer research method (sometimes called user-focused research), a form of research steered and conducted by people with a lived experience of the issue under study. In each group of students, one acted as a 'researcher', taking pictures, videos and leading short interviews. 
Although very different in terms of age, family background and emotional engagement, the respondents generally identified easily with the main functions of the application, as they understood them: to commemorate Holocaust victims in public space and to relate their stories and faces to specific locations. All groups also wished to add guided routes to the application, to provide a more detailed insight into the life stories of specific individuals and historical context. All were attracted by the visual material - the historical photographs of houses and streets, and portraits of Holocaust victims. They suggested that in the absence of a personal photograph, an icon visually indicating gender should be used.
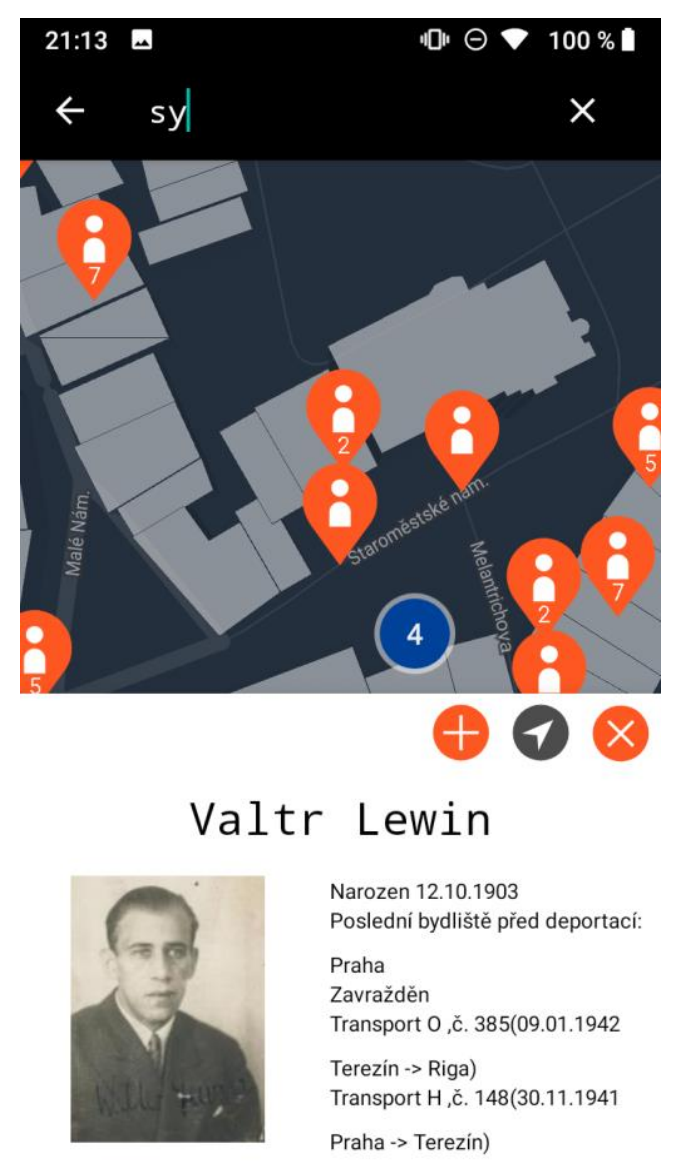

$<$

Figure 3: Development version of the application, showing map with personal information 
Users asked for greater clarity and comprehensibility of the map base. They pointed out the need to display house numbers, and to show street names and landmark buildings, even the non-Jewish ones, clearly. Some expressed concern that the map showing the contemporary street plan and names is confusing, especially for users from outside Prague. Students from both schools, used to working with mobile applications, asked questions about data consumption or the possibility to download application data via Wi-Fi and then work offline. Useful comments also related to the application functionality: the possibility of selecting a particular time span on the timeline was requested, as were colour differentiation for the points or people already visited, and the option to collapse the toolbar and show a full-screen map. Children of Holocaust survivors reflected primarily on the connection to their family history and emphasized ethical aspects of publishing photographs of people with living relatives. They also expressed their concern about possible anti-Semitic reactions.

In the future, more testing will be required regarding the use of archival documents on mobile devices and in space. Reading can be made difficult by the presentation of handwritten texts, in German or other languages, or insufficient understanding of bureaucratic procedure and administrative jargon from the period. In the next phase, the testing process will focus on the tension encoded in the history of the public space in Prague, and the shifting between presence and absence of Jewish life.

\section{Going forward}

Cooperation in the interdisciplinary team proved to be a challenging yet enriching learning process. Following an agile development pattern, the work did not follow a straightforward, linear design but rather one in which all aspects regarding data and functionality needed to be revisited regularly based on user testing, further evaluation and discussion.

The project work has been delayed by the Covid-19 pandemic, making not only the development, but also (and mainly) testing difficult. This article was finished just as a new test version of the application, with the full dataset and upgraded functionality, became available. In the near future, the team will re-evaluate the effects on the user's perception of space and any critical reflection on its social construction. Ideally, after the final release of the application in 2021, students, residents and tourists in Prague will be able not only to commemorate Prague's Jews who were deported and murdered, but also to reflect on the history of the shared and contested space of Prague.

In the longer term, the project team will focus on the sustainability of the software and extending its functionality for the Prague application, as well as on its possible deployment in other spaces. Discussions will also be held with EHRI and its future national nodes to assess how this and similar projects may be supported by providing data services or in other ways. 


\section{Acknowledgement}

This article was supported by the Technology Agency of the Czech Republic (TAČR) under the project TL01000366 'Integration and Segregation in Cityspace: The History of the Holocaust in Prague Through a Web Application'.

\section{References}

Adler, H. G. (1960). Theresienstadt, 1941-1945. Das Antlitz einer Zwangsgemeinschaft. Geschichte, Soziologie, Psychologie. Mohr.

Bollini L., De Palma R., Nota R., Pietra R. (2014). User Experience \& Usability for Mobile Georeferenced Apps. A Case Study Applied to Cultural Heritage Field. ICCS A, 2, 652-662.

Bondy, R. (1989). 'Elder of the Jews'. Jakob Edelstein of Theresienstadt. Grove.

Čapková, K., \& Frankl, M. (2012). Unsichere Zuflucht: Die Tschechoslowakei und ibre Flüchtlinge aus NS Deutschland und Österreich 1933-1938 (1st ed.). Böhlau.

Černý, B. (1997). Emigrace Židů z Českých zemí v letech 1938-1941. Terezínské studie a dokumenty, 5571.

Cohen, G. B. (1977). Jews in German Society: Prague, 1860-1914. Central European History, 10(1), 28 54.

Cohen, G. B. (1981). The Politics of Ethnic Survival. Germans in Prague, 1861-1914. Princeton University Press.

Cole, T. (2016). Holocaust landscapes. Bloomsbury Continuum.

Delamont, S. (Ed.). (2012). Handbook of qualitative research in education. Cheltenham: Edward Elgar.

Denzin, N. K., \& Lincoln, Y. S. (Eds). (2011). The Sage handbook of qualitative research (4th edn). Thousand Oaks: Sage.

Giustino, C. M. (2003a). Municipal Activism in Late-Nineteenth-Century Prague. The House Numbered 207-V and Ghetto Clearance. Austrian History Yearbook, 34, 247-278.

Giustino, C. M. (2003b). Tearing Down Prague's Jewish Town. Ghetto Clearance and the Legacy of Middle-Class Ethnic Politics around 1900. Boulder: Columbia University Press.

Gruber, R. E. (2002). Virtually Jewish. Reinventing Jewish culture in Europe. University of California Press.

Gruner, W. (2016). Die Judenverfolgung im Protektorat Böhmen und Mähren. Lokale Initiativen, zentrale Entscheidungen, jüdische Antworten 1939-1945. Wallstein-Verlag.

Hrůza, J. (Ed.). (1993). Pražská asanace. K 100. výroči vydáni asanačního zákona pro Prabu. Muzeum hlavního města Prahy.

Kárný, M. (1991). 'Konečné résèní. Genocida českých židů v nèmecké protektorátní politice. Academia.

Kárná, M. (1993). Dětští vězňové Terezína. Terezínská iniciativa, 4, 7-13.

Kárný, M. (Ed.). (1995). Terezínská pamétní kniba. Židovské obèti nacistických deportací z Céch a Moravy 1941 1945 (Vols 1-2). Terezínská iniciativa - Melantrich.

Knowles, A. K., Cole, T., \& Giordano, A. (Eds). (2014). Geographies of the Holocaust. Indiana University Press.

Koeltzsch, I. (2012). Geteilte Kulturen. Eine Geschichte der tschechisch-jüdisch-deutschen Beqiehungen in Prag (1918-1938). Oldenbourg.

Kosta, J. (2001). Nie aufgegeben. Ein Leben zuischen Bangen und Hoffen. Philo; originál.

Krejčová, H., Svobodová, J., \& Hyndráková, A. (1997). Židé v Protektorátu. Die Juden im Protektorat Böhmen und Mähren. Hláseni Židovské náboženské obce v roce 1942. Dokumenty. Ústav pro soudobé dějiny AV ČR - Maxdorf.

Lichtman, M. V. (2012). Qualitative Research in Education: A User's Guide (3rd edn). Los Angeles ; London: SAGE Publications. 
Milotová, J. (1997). Die Zentralstelle für jüdische Auswanderung in Prag. Genesis und Tätigkeit bis zum Anfang des Jahres 1940. Theresienstädter Studien und Dokumente.

Plzáková, A., \& Štěpková, T. (2015). Databáze obětí holocaustu Institutu Terezínské iniciativy. In Sbornik Semináre o digitálních zdrojich a službách ve společenských a bumanitních vědách: 24. Zárí 2015 (pp. 109-112). Univerzita Karlova v Praze, Matematicko-fyzikální fakulta.

Schellenbacher, W. (2017). Memento Vienna: A Case Study in Digital Archives, Georeferenced Data and Holocaust Education. GI_Forum, 1, 13-22. https://doi.org/10.1553/giscience2017_02_s13

Šmok, M. (2015). Stopy židovské prítomnosti v Praže 2 / Traces of Jewish Presence in Prague 2. Vydala městská část Praha 2.

Spilka, B. (Ed.). (1945). Teręin-Ghetto (1st edn). Repatriační odbor ministerstva ochrany práce a sociální péče Republiky československé.

Terezin memorial book. Jewish victims of nazi deportations from Bohemia and Moravia 1941-1945. A guide to the Caech original with a glossary of Czech terms used in the lists. (1996). Melantrich.

Theresienstädter Gedenkbuch. Die Opfer der Judentransporte aus Deutschland nach Theresienstadt 1942-1945 (Vyd. 1). (2000). Academia: Institut Theresienstädter Initiative; Metropol.

Theresienstädter Gedenkbuch. Österreichische Jüdinnen und Juden in Theresienstadt 1942-1945. (2005). Institut Theresienstädter Initiative: Dokumentationsarchiv des österreichischen Widerstandes.

Veselská, M. (2012). Archa pamèti. Cesta pražskébo židovskébo muzéa pobnutým 20. stoletím. Academia: Židovské muzeum v Praze. 